\title{
The Comparison of Scientist Perceptions of Syrian Refugee Students and Turkish Students: Sample of Mersin Province
}

\author{
Ümit İzgi Onbaşılı*
}

\begin{abstract}
The objective of this study is to compare scientist perception of students who migrated from Syria to Turkey in recent years in primary school age and Turkish students. Descriptive research method is used in this study. The study was conducted with a total of 109 students as Syrian (36) and Turkish (73) attending a public school in third and fourth grades in Mersin Province in 2017-2018 academic year. In the research, Draw A Scientest Test-DAST which were developed by Chambers (1983) was applied as data collection tool. The analysis of the drawings was made with reference to codes and themes developed by Chambers (1983), Korkmaz and Kavak (2010), Song and Kim (1999). In the drawings of students; the codings were performed according to the themes of (1) physical characteristics of scientist, (2) his/her gender, (3) research symbols s/he used, (4) knowledge symbols s/he used, (5) technology, (6) study field and (7) favourite scientists. When the drawings are examined all male children both Syrian and Turkish drawed a "male" figure when scientist is called. As for the physical characteristics of scientist, both student groups described scientist as his/her hair combed properly, well groomed. While Syrian students give place to symbols of microscope, clock, palette, lightbulb, ship, Turkish students give place to many more various symbols relevant to research symbols scientist used. The images which they reflected related to knowledge symbols used by scientist differs as well. It is seen that common images of Syrian and Turkish children related to technology are time machine, spaceship, flying car and flying house. While the drawings are examined under the category of favourite scientist; "Thomas Edison" took the first place in the ranking of favourite scientist for both Syrian and Turkish students. As a result of this research, it is seen that Syrian students generally give more limited answers about the perception of scientists than Turkish students. Children have difficulty in drawing according to Turkish students since they cannot express themselves in a language other than their mother tongue. In this context, suggestions were made about the integration of Syrian students into the education process.
\end{abstract}

Keywords: Syrian refugee student, primary education, scientist perception

\footnotetext{
* Assist. Prof. Dr., Mersin University, Faculty of Education, Department of Primary School Education, Mersin, Turkey. E-mail: umitizgi@gmail.com
} 


\title{
Suriyeli Mülteci Öğrencilerle Türk Öğrencilerin Bilim İnsanı Algılarının Karşılaştırılması: Mersin İli Örneği
}

\author{
$\ddot{\mathbf{O z}}$
}

\begin{abstract}
Bu çalışmanın amacı, son yıllarda Suriye'den Türkiye'ye göç eden ilkokul çağındaki öğrencilerle Türk öğrencilerin bilim insanı algılarını kıyaslamaktır. Çalışmada betimsel araştırma yöntemi kullanılmıştır. Araştırma 2017-2018 eğitim öğretim döneminde Mersin İli'nde bulunan bir devlet okuluna kayıtlı üçüncü ve dördüncü sınıfa devam eden Suriyeli (36) ve Türk (73) toplamda 109 öğrenciyle yürütülmüsştür. Araştırmada veri toplama arac1 olarak Chambers (1983) tarafindan geliştirilen "Bir Bilim İnsanı Çiz Testi" (Draw A Scientest Test-DAST) uygulanmıştır. Çizimlerin analizi Chambers (1983), Korkmaz ve Kavak (2010), Song ve Kim (1999) tarafından geliştirilen kod ve temalar referans alınarak yapılmıştır. Öğrencilerin çizimlerinde; (1) bilim insanının fiziksel özellikleri, (2) cinsiyeti, (3) kullandığı araştırma sembolleri, (4) kullandığı bilgi sembolleri, (5) teknoloji, (6) çalışma alanı ve (7) favori bilim insanları temalarına göre kodlamalar yapılmıştır. Çizimler incelendiğinde hem Türk hem Suriyeli tüm erkek çocuklar, bilim insanı denildiğinde "erkek" figür çizmiştir. Bilim insanının fiziksel özelliklerine ilişkin olarak her iki öğrenci grubu da bilim insanını, saçı düzgün taranmış, üstü başı düzgün kıyafetli olarak anlatmışlardır. Bilim insanının kullandığı araştırma sembolllerine ilişkin, Suriyeli öğrenciler mikroskop, saat, resim paleti, ampul, gemi sembollerine yer verirken, Türk öğrenciler çok daha çeşitli araştırma sembollerine yer vermişlerdir. Bilim insanının kullandığı bilgi sembollerine yönelik yansıttıkları imajlar da farklılık göstermektedir. Suriyeli ve Türk çocukların teknolojiye yönelik ortak imajlarının zaman makinası, uzay gemisi, uçan araba ve uçan ev olduğu görülmektedir. Türk öğrencilerin büyük bir çoğunluğu bilim insanının laboratuvarda deneyler yaparken çizerken, Suriyeli öğrenciler daha çok doğada ve evde çalışırken çizmişlerdir. Favori bilim insanı başlığında çizimler incelendiğinde, "Thomas Edison" hem Suriyeli hem Türk öğrencilerin favori bilim insanı sıralamasında birinci sırada yer almıştır. Bu araştırma soncunda genel olarak Suriyeli öğrencilerin Türk öğrencilere göre bilim insanı algısıyla ilgili daha sınırlı cevaplar verdikleri görülmektedir. Uygulama için gidilen okulda Suriyeli öğrencilerle dil konusunda sıkıntılar yaşandığı görülmüştür. Çocuklar ana dillerinden başka bir dilde kendilerini rahat ifade edemedikleri için çizim konusunda Türk öğrencilere göre zorlanmışlardır. Bu bağlamda Suriyeli öğrencilerin eğitim-öğretim sürecine entegrasyonu konusunda önerilerde bulunulmuştur.
\end{abstract}

Anahtar Sözcükler: Suriyeli mülteci öğrenci, ilköğretim, bilim insanı algısı 


\section{Introduction}

The population of refugees and immigrants is increasing in recent years due to the factors such as war, unemployment (İdin, 2018). When the psychological basis of education is thought, some variables emerged by migration movements started to find more place in school systems of today; concepts such as educational acceptance, perception, communication, attitude, belief, empathy, fear, support are seen more frequently in researchs (Nguyen \& BenetMartínez, 2013; cit.: Sak1z, 2016, p.65). After the Syrian civil war started in 2011, more than four million people were forced to leave their homeland and more than half of these individuals are children (UNHCR, 2015; cit.: Sak1z, 2016, p.66). Education processes of children and youngsters are among the subjects which are most affected from the conflicts in Syria. Because the schools closed substantially since 2011 when the events started, there is a period which was spent without education for Syrian children before they come to Turkey. The asylum case surplusing the predicted numbers and periods exceedingly increased the importance of education need. (Seydi, 2014, p.268).

When the studies conducted relevant to Syrian children are examined, it is seen that these children experience serious difficulties in complying with their educational institution. The most important common point is that children experience great problems due to not knowing Turkish. Since they don't know Turkish, they can not communicate with both their teachers and compeers. So, they can not socialize and stay out of the group (Uzun and Bütün, 2016, p.72). Similarly, İdin (2018) in his study which he conducted within the scope of science classes with refugee students, he concluded that refugee students were not able to comprehend what their teachers say in science classes. Also in this study, according to science teachers the factors such as students not knowing Turkish, not feeling that they belong to Turkey, economical reasons and negative school environment are effective in students failing in science classes (İdin, 2018).

In general, adaptation to school process (Yavuz and Mizrak, 2016), language problem (Büyükikiz and Çangal, 2016), their failures in lessons, teacher opinions related to this students (Uzun and Bütün, 2016) were studied with the Syrian students in our country. But it was not possible to encounter a study which was conducted with their perspectives of science, with their scientist perceptions in addition to academic achievements of these students. Science perception was studied with Turkish students so many times through different samples (Korkmaz and Kavak, 2010; Toğrol, 2000; Türkmen, 2008). But another study which compares scientist perception of Syrian students and Turkish students was not encountered.

In the literature, study conducted by Mead and Metraux (1957) is encountered as the first study which were carried out with regards to "scientist" concept. They examined scientist perception of students in detail by asking them open-ended questions in the study they conducted with high school students in United States of America. According to the result of this study students generally describe scientist as "someone who puts on a white coat, works in the laboratory, is middle aged/aged, wears glasses, is bearded, has test tubes around, making experiments all the time, observes with a microscope, observes about plants and animals, writing on a black and white blocknote..." (Mead and Metraux,1957, p.386-387). In addition, in this study both positive and negative perceptions related to scientist were determined. They described the positive specialities of a scientist as "genious, very hard-working, dedicated, someone who does not do this job for money, and who conduct useful studies for his/her country and humankind", on the other hand, they described their positive specialities as "someone who works in an indoor environment all day, can not be successful even though he/she studies for years, reads book all day and can't go to the house, can not spare enough time for his/her spouse and children, can not get married or not preferred for marriage, make some dangerous experiments" (Mead and Metraux,1957, p.386-387). Mead and Metraux (1957) who make various suggestions specified that educators should start awareness studies with regards to science and scientist perception beginning from preschool period and primary school. They especially mentioned about the importance of increasing the interest of female students against science and they emphasized that this should be encouraged. It is also shared within the scope of this study that it should be mentioned that scientists don't conduct only individual studies, but also teamwork. Mead and Metraux (1957) created a very significant awareness with regards to "scientist" perception in the education world. Afterwards, so many 


\section{THE COMPARISON OF SCIENTIST PERCEPTIONS OF SYRIAN REFUGEE STUDENTS AND TURKISH STUDENTS: SAMPLE OF MERSIN PROVINCE}

researchs on various samples continued to be conducted. Chambers (1983) wanted to determine "Scientist" perception with a drawing test instead of open-ended questions or likert scale which were used before. Draw A Scientists Test-DAST was applied on so many students in different age groups, it took its place in the literature as a valid and reliable measurement tool.

Balk1, Çoban and Aktaş (2003) have asked students to open-ended questions about the nature of science and scientists. At the end of the study, it was observed that the students confuse the nature of science and the work of scientists'. In addition, it appears that most of the students said that reading a lot of books was enough to become a scientist and that there would not be anything without science. It is stated that the answers given by the students are limited due to the fact that science courses are not as qualified as their competence.

Korkmaz and Kavak (2010) investigated the images of primary school students towards informatics and scientists at gender and class level. As the study area of the scientist, students at all grade levels draw the most "laboratories". Also it is seen that most of the male students draw the scientists as male and the female students draw the scientists as female. When evaluated on a class basis, it is observed that the most male scientist figure is used at all class levels.

In this study, Chambers (1983) Draw A Scientists Test-DAST was used. This study was conducted in order to compare especially scientist perceptions of Turkish students and Syrian refugee students in primary school level who attend public schools in Mersin Province currently and who had to immigrate from Syria recently. Mersin Province is among the cities which most allow immigrants in recent years. In this context, Draw A Scientists Test-DAST which was conducted previously on different samples both in our country and in different countries was applied on Syrian refugee students within the scope of this study. It was dwelled on what can be done in the integration of especially refugee students to Turkish Education System by examining scientist perception of two different student groups (difference of their educational background, immigration conditions, etc.) which are included in the same education system.

\section{Research Problem} school?

How is the scientist perception of Syrian and Turkish students attending to primary

\section{Sub Problems}

1) How is the scientist perception of Syrian students attending to primary school?

2) How is the scientist perception of Turkish students attending to primary school?

3) Is there a difference between scientist perception of Syrian and Turkish students attending to primary school?

4) Do the scientist perceptions of Syrian and Turkish students attending to primary school differ according to gender?

\section{Method}

\section{Research Model}

Descriptive research method is used in this study. Description; tries to explain events, objects, entities, institutions, groups and various fields are "what" (Karasar, 1999). The data of the study were analyzed using quantitative and qualitative research techniques. Qualitative research can be stated as a research approach which qualitative data collection techniques such as observation, interview, document analysis are used and a qualitative process is applied regarding to setting forth of perceptions and events in a natural environment in a realistic and integrative way (Yıldırım \& Şimşek, p. 39). 


\section{Study Group}

It was targeted within the scope of availability sampling to reach all of the Syrian students in a school by contacting a public school which have so many Syrian students in Yenişehir Subprovince of Mersin Province within the scope of the study. There is a total of 70 Syrian students in the school. All Syrian students who were registered to first, second, third and fourth grades were reached within the scope of the study. However, Syrian students attending to first and second grades still have difficulty about language. Surveying tools were tried to be applied to every student under the guidance of form teachers with the researcher. Since it was seen during the implementation that first and second grade Syrian students couldn't comprehend the concepts of "science and scientist" at all, the research was able to be carried out only with the Syrian students (36 students) in the third and fourth grade. Same surveying tool were implemented also to Turkish students (73 students) in the classrooms of Syrian students participating in the research. Thus scientist perceptions of 109 Syrian and Turkish students in total who study in the same classroom with the same teacher were examined in detail. The distribution of Syrian and Turkish students within the scope of the study is given in Table 1.

Table 1. The distribution of Syrian and Turkish students within the scope of the study

\begin{tabular}{lccc}
\hline & Female & Male & Total \\
\hline Syrian Students & 17 & 19 & 36 \\
\hline Turkish Students & 47 & 26 & 73 \\
\hline Total & 64 & 45 & 109 \\
\hline
\end{tabular}

\section{Data Collection Tool}

In this study Draw A Scientists Test-DAST of Chambers (1983) was used.

\section{Analysis of the Data}

The analysis of the drawings was made with reference to codes and themes developed by Chambers (1983), Korkmaz and Kavak (2010), Song and Kim (1999). In the analysis of Chambers (1983:258) DAST test, as the standart (stereotype) specialities of scientist / different criteria are used as;

1. Laboratory coat (especially white)

2. Glasses

3. Facial hair (hair, beard, moustache)

4. Research symbols (scientific tools and laboratory equipment)

5. Knowledge symbols (books and full shelves)

6. Technology (product of science)

7. Related titles (formulas, taxonomic classification, statements such as "I've found itEureka", etc.)

The codes acquired by researchers were thematised also by considering the criteria used in DAST analysis. In the drawings of students; codings were performed according to the themes of (1) physical characteristics of scientist, (2) his/her gender, (3) research symbols s/he used, (4) knowledge symbols s/he used, (5) technology, (6) study field and (7) favourite scientists. After the examinations, drawings made by students was coded by two different researchers. Reliability formula [Consensus / (Consensus+Disagreement)] of Miles ve Huberman (1994) was used for the reliability o the codes acquired and reliability coefficient of the codes were determined as 0.90 . 


\section{Findings}

The images of students related to physical characteristics of scientist are given as gender and as Syrian-Turkish students seperately in Table 2.

Table 2. Frequency and percentage distribution of images related to physical characteristics of scientist

\begin{tabular}{lcccc}
\hline & \multicolumn{2}{c}{ Syrian } & \multicolumn{2}{c}{ Turkish } \\
\hline Gender & $\begin{array}{c}\text { Female } \\
\mathrm{f}(\%)\end{array}$ & $\begin{array}{c}\text { Male } \\
\mathrm{f}(\%)\end{array}$ & $\begin{array}{c}\text { Female } \\
\mathrm{f}(\%)\end{array}$ & $\begin{array}{c}\text { Male } \\
\mathrm{f}(\%)\end{array}$ \\
\hline Wearing laboratory coat & $1(2.8 \%)$ & 0 & $6(8.2 \%)$ & $3(4.1 \% 9$ \\
Wearing astronot suit & 0 & 0 & $1(1.4 \%)$ & $2(2.7 \%)$ \\
Wearing woman dress & $4(11.1 \%)$ & 0 & $12(16.4 \%)$ & 0 \\
Wearing suit & $2(5.6 \%)$ & $1(2.8 \%)$ & $12(16.4 \%)$ & $3(4.1 \%)$ \\
Wearing a hat & $3(8.3 \%)$ & $1(2.8 \%)$ & 0 & $1(1.4 \%)$ \\
Wearing a turban & $1(2.8 \%)$ & 0 & 0 & $1(1.4 \%)$ \\
Wearing glasses & $1(2.8 \%)$ & $1(2.8 \%)$ & $2(2.7 \%)$ & $2(2.7 \%)$ \\
Freckled & 0 & 0 & $1(1.4 \%)$ & 0 \\
Bearded & $1(2.8 \%)$ & $1(2.8 \%)$ & $4(5.5 \%)$ & $5(6.8 \%)$ \\
Moustached & $2(5.6 \%)$ & $1(2.8 \%)$ & $2(2.7 \%)$ & $4(5.5 \%)$ \\
Dishevelled & 0 & 0 & $2(2.7 \%)$ & $3(4.1 \%)$ \\
Straggly & $2(5.6 \%)$ & 0 & $6(8.2 \%)$ & $4(5.5 \%)$ \\
Having rough hair & 0 & $5(13.9 \%)$ & $8(11 \%)$ & $4(5.5 \%)$ \\
Having firmly combed hair & $8(22.2 \%)$ & $1(2.8 \%)$ & $25(34.2 \%)$ & $6(8.2 \%)$ \\
Wearing an earring & $1(2.8 \%)$ & 0 & 0 & 0 \\
Blind & 0 & 0 & $1(1.4 \%)$ & 0 \\
Using crutches & 0 & 0 & 0 & $1(1.4 \%)$ \\
Police & 0 & $3(8.3 \%)$ & $1(1.4 \%)$ & 0 \\
\hline
\end{tabular}

When the images reflected by students with regards to physical characteristics of scientist in their drawings are examined in general; it is seen that scientist perception is in general as; "having firmly combed hair" ( $\mathrm{n}=40)$, " a man wearing suit" $(\mathrm{n}=18)$, "wearing woman dress" $(n=16)$, " Wearing glasses" ( $n=6)$, " Bearded" ( $n=11)$, "Moustached" ( $n=9)$. When the drawings of students are examined, it is seen that especially Syrian female students made more detailed drawings compared to Syrian male students (While female students drew a total of $\mathrm{n}=26$ images, male students drew $\mathrm{n}=14$ images in total). When they are compared acoording to their gender and nationalities the most attention-grabbing findings are; while both Syrian $(\mathrm{n}=4)$ and Turkish $(\mathrm{n}=12)$ female students perceives scientists as "someone who wears woman dress", it is seen that any male students have this perception. Male students generally draw scientist as someone "wearing laboratory coat" (Turkish male students $n=3$; Syrian male students $n=1$ ), "Wearing suit" (Turkish male students $n=3$; Syrian male students $n=1$ ). While Turkish students draw "astronot suit" with regards to scientist, such an answer did not come out from Syrian students. $(n=4)$ of Syrian students consubstantiate scientist with "police". It is clearly seen that most of the Syrian students used the themes of police, Turkish flag, plane, car in their drawings frequently due to the war process they had experienced. 

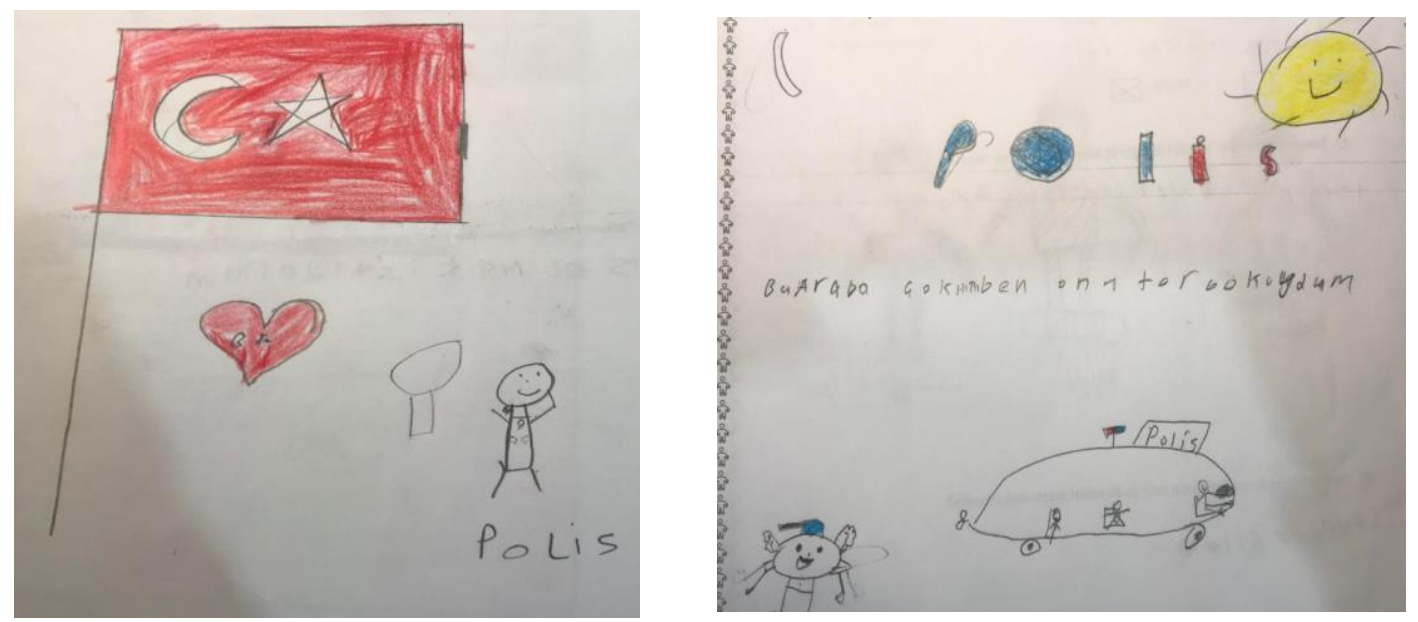

Figure 1 and 2: Emulating scientist to policeman and drawing of Turkish flag. The drawing on the left (Syrian student, Male, 3. grade), the drawing on the right (Syrian student, Male, 4. grade)

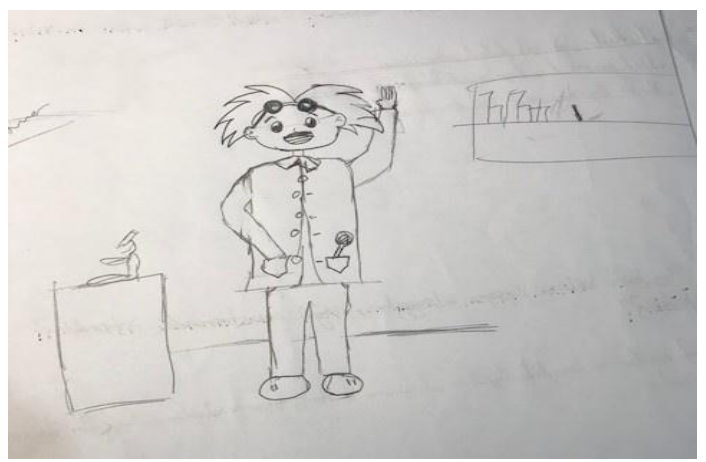

Figure 3: A male scientist wearing coat and glasses with messy hair (Syrian, Female, 4. grade)

The images of students related to the gender of scientist are given as gender and as SyrianTurkish students seperately in Table 3.

Table 3. Frequency and percentage distribution of images related to gender of scientist whom students reflected in their drawings

\begin{tabular}{lcccc}
\hline & \multicolumn{2}{c}{ Syrian } & \multicolumn{2}{c}{ Turkish } \\
\hline Gender & $\begin{array}{c}\text { Female } \\
\mathrm{f}(\%)\end{array}$ & $\begin{array}{c}\text { Male } \\
\mathrm{f}(\%)\end{array}$ & $\begin{array}{c}\text { Female } \\
\mathrm{f}(\%)\end{array}$ & $\begin{array}{c}\text { Male } \\
\mathrm{f}(\%)\end{array}$ \\
\hline Female & $11(30.6 \%)$ & 0 & $21(28.8 \%)$ & 0 \\
Male & $6(16.7 \%)$ & $19(52.8 \%)$ & $26(35.6 \%)$ & $26(35.6 \%)$ \\
\hline
\end{tabular}

When the images reflected by students with regards to gender of scientist in their drawings are examined in general; $(n=11)$ of Syrian female students and $(n=21)$ of Turkish female students drew scientist as "female". All Syrian and Turkish male students reflected the scientist as "male". 


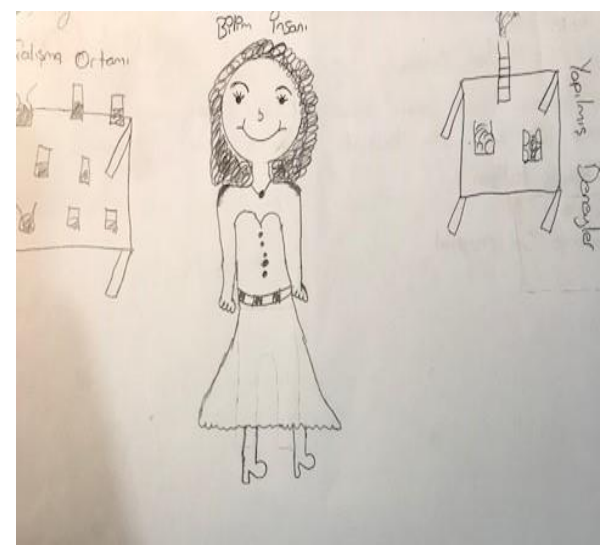

Figure 4: A female scientist with a dress (Turkish, Female, 4. grade)

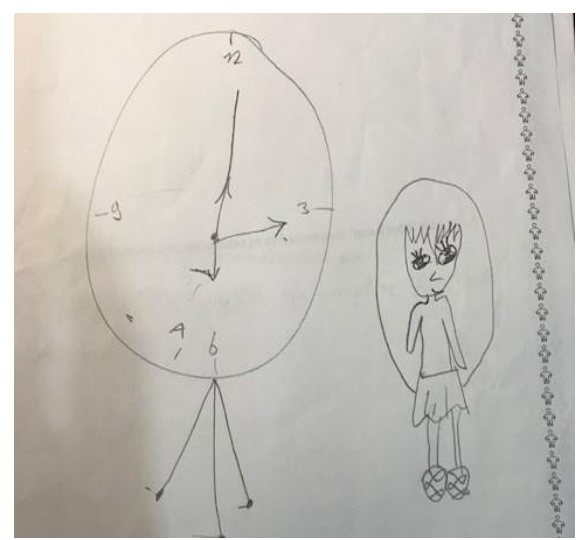

Figure 5: A female scientist with a dress (Syrian, Female, 3. grade)

The images of students related to research symbols used by scientist are given as gender and as Syrian-Turkish students seperately in Table 4.

Table 4. Frequency and percentage distribution of images related to research symbols used by scientist whom students reflected in their drawings

\begin{tabular}{lcccc}
\hline & \multicolumn{2}{c}{ Syrian } & \multicolumn{2}{c}{ Turk } \\
\hline Research symbols & $\begin{array}{c}\text { Female } \\
\mathrm{f}(\%)\end{array}$ & $\begin{array}{c}\text { Male } \\
\mathrm{f}(\%)\end{array}$ & $\begin{array}{c}\text { Female } \\
\mathrm{f}(\%)\end{array}$ & Male \\
& 0 & 0 & $15(20.5 \%)$ & $6(8.2 \%)$ \\
\hline Test tube & 0 & 0 & $1(1.4 \%)$ & $1(1.4 \%)$ \\
Planet & $1(2.8 \%)$ & 0 & 0 & $1(1.4 \%)$ \\
Microscope & 0 & 0 & 0 & $1(1.4 \%)$ \\
Dinasaur & 0 & 0 & 0 & $2(2.7 \%)$ \\
Atom & $(2.8 \%)$ & 0 & $3(4.1 \%)$ & $1(1.4 \%)$ \\
Clock & 0 & 0 & $1(1.4 \%)$ & 0 \\
Table (Poster) & 0 & 0 & 0 & $1(1.4 \%)$ \\
Magnifier & 0 & $1(2.8 \%)$ & $4(5.5 \%)$ & $5(6.8 \%)$ \\
Bulb & 0 & 0 & 0 & $1(1.4 \%)$ \\
Telescope & 0 & 0 & 0 & $2(2.7 \%)$ \\
Fossil & 0 & 0 & $12(16.4 \%)$ & $6(8.2 \%)$ \\
Table & 0 & 0 & $1(1.4 \%)$ & $1(1.4 \%)$ \\
Closet & 0 & $2(5.6 \%)$ & $1(1.4 \%)$ & 0 \\
Ship & $(2.8 \%)$ & $1(2.8 \%)$ & $1(1.4 \%)$ & 0 \\
Pallet & 0 & 0 & $1(1.4 \%)$ & 0 \\
Insect & 0 & 0 & $1(1.4 \%)$ & 0 \\
Stethoscope & 0 & 0 & $2(2.7 \%)$ & $1(1.4 \%)$ \\
Vaccine & 0 & 0 & 0 & $1(1.4 \%)$ \\
Tool - Equipment & 0 & 0 & 0 & $1(1.4 \%)$ \\
Medicine & 0 & 0 & 0 & $1(1.4 \%)$ \\
Chair & 0 & 0 & 0 & $1(1.4 \%)$ \\
Dog & 0 & 0 & $1(1.4 \%)$ & 0 \\
Scales & 0 & 0 & $1(1.4 \%)$ & 0 \\
Organs & & 0 & & 0 \\
\hline
\end{tabular}

When the images reflected by students with regards to research symbols used by scientist in their drawings are examined in general; it is seen that Syrian students gave place to less research symbols compared to Turkish students. $(n=1)$ of Syrian female students drew "microscope", $(n=1)$ "clock" and $(n=1)$ "pallet". Syrian female students drew $(n=1)$ "bulb" and $(n=2)$ "ship". When the drawings of Turkish students are examined, it is seen that they gave place to many various symbols (vaccine, stethoscope, organs, scales, medicine, fossile, 
telescope, atom, dinosaur, planet). In general, the symbols which both Syrian and Turkish students drew in common are encountered as pallet, microscope, ship, bulb and clock.

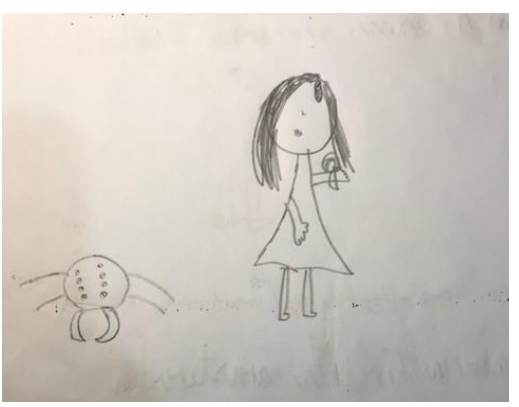

Figure 6. A female scientist researching insects (Turkish, Female, 4. grade)

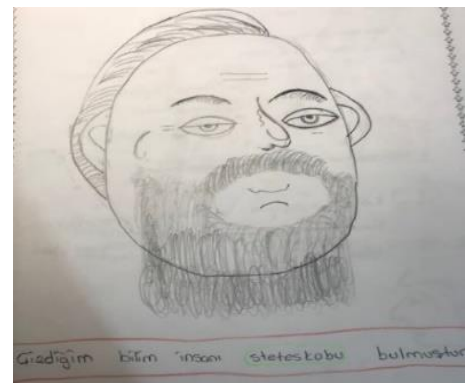

Figure 7: A scientist who invented stethoscope (Turkish, Female, 4. grade)

The images of students related to knowledge symbols used by scientist are given as gender and as Syrian-Turkish students seperately in Table 5.

Table 5. Frequency and percentage distribution of images related to knowledge symbols used by scientist whom students reflected in their drawings

\begin{tabular}{lcccc}
\hline & \multicolumn{2}{c}{ Syrian } & \multicolumn{2}{c}{ Turkish } \\
\hline Knowledge Symbols & $\begin{array}{c}\text { Female } \\
\mathrm{f}(\%)\end{array}$ & $\begin{array}{c}\text { Male } \\
\mathrm{f}(\%)\end{array}$ & $\begin{array}{c}\text { Female } \\
\mathrm{f}(\%)\end{array}$ & $\begin{array}{c}\text { Male } \\
\mathrm{f}(\%)\end{array}$ \\
\hline Book & 0 & 0 & $3(4.1 \%)$ & $1(1.4 \%)$ \\
\hline Pen & $1(2.8 \%)$ & $1(2.8 \%)$ & $1(1.4 \%)$ & 0 \\
\hline Formulas & 0 & 0 & $4(5.5 \%)$ & $2(2.7 \%)$ \\
\hline Board & $2(5.6 \%)$ & 0 & 0 & 0 \\
\hline Coordinates & 0 & 0 & 0 & $1(1.4 \%)$ \\
\hline Dry ice & 0 & 0 & 0 & 0 \\
\hline Gravity & 0 & 0 & $2(2.7 \%)$ & 0 \\
\hline Virus & 0 & 0 & $1(1.4 \%)$ & 0 \\
\hline Micrope & 0 & 0 & & 0 \\
\hline
\end{tabular}

When the images reflected by students with regards to knowledge symbols used by scientist in their drawings are examined in general; it is seen that Syrian students used only two symbols. These are "pen" and "board". When the drawings of Turkish students are examined, it is seen that they gave place to symbols of "book", "pen", "formulas", "coordinates", "dry ice", "gravity", "virus", "micrope".

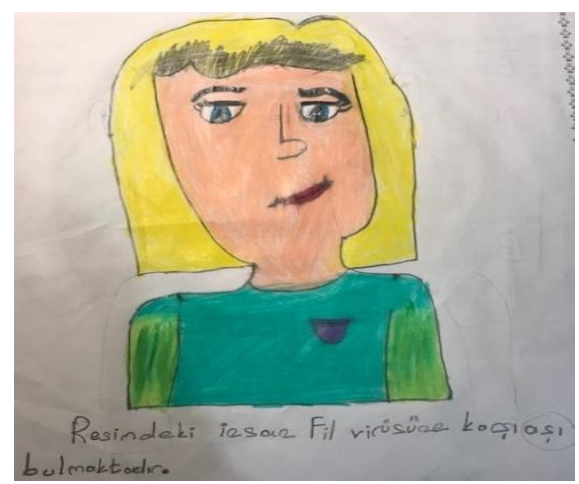

Figure 8: Figure 8: A female scientist researching viruses (Turkish, Female, 4. Grade)

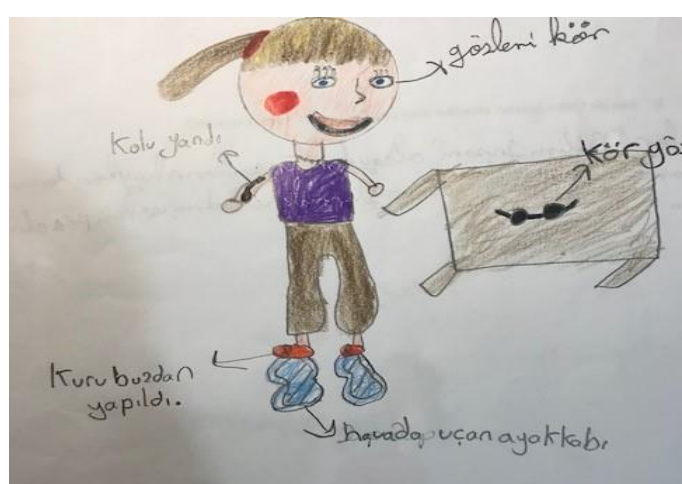

Figure 9: A female scientist making experiment with dry ice (Turkish, Female, 3. Grade) 


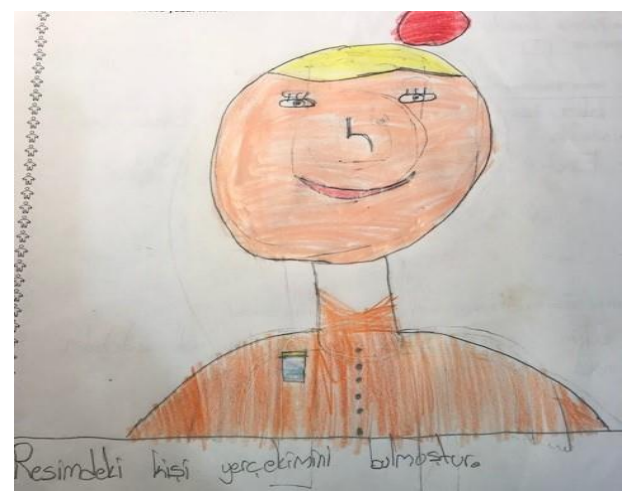

Figure 10: Scientist who an apple falling on his head and finding gravity

(Turkish, Male, 3. Grade)

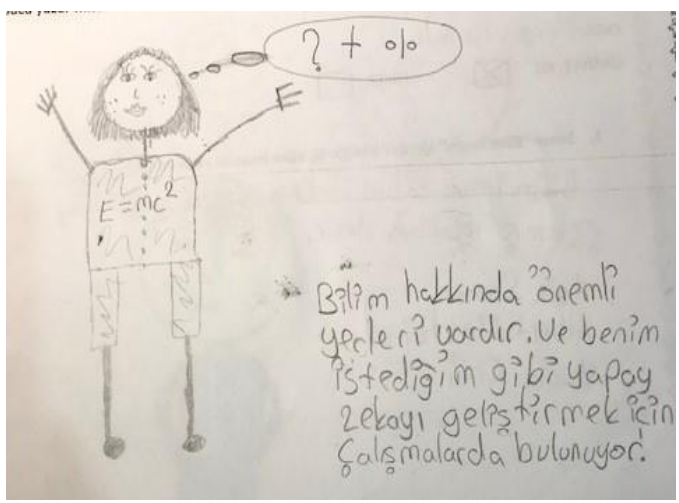

Figure 11: A female scientist who makes calculations with formulas and researches artificial intelligence

(Turkish, Female, 4. Grade)

The images of students related to technology used by scientist are given as gender and as Syrian-Turkish students seperately in Table 6.

Table 6. Frequency and percentage distribution of images related to technology used by scientist

\begin{tabular}{lcccc}
\hline & \multicolumn{2}{c}{ Syrian } & \multicolumn{2}{c}{ Turkish } \\
\hline Technology & $\begin{array}{c}\text { Female } \\
\mathrm{f}(\%)\end{array}$ & $\begin{array}{c}\text { Male } \\
\mathrm{f}(\%)\end{array}$ & $\begin{array}{c}\text { Female } \\
\mathrm{f}(\%)\end{array}$ & $\begin{array}{c}\text { Male } \\
\mathrm{f}(\%)\end{array}$ \\
\hline Washing machine & 0 & $1(2.8 \%)$ & 0 & 0 \\
Time (teleportation) & $1(2.8 \%)$ & 0 & $2(2.7 \%)$ & $2(2.7 \%)$ \\
Computer & 0 & 0 & $1(1.4 \%)$ & $1(1.4 \%)$ \\
Tablet & 0 & $1(2.8 \%)$ & 0 & 0 \\
Robot & 0 & $2(5.6 \%)$ & $3(4.1 \%)$ & $3(4.1 \%)$ \\
Telephone & $12.8 \%)$ & $1(2.8 \%)$ & $1(1.4 \%)$ & 0 \\
Spaceship & 0 & $2(5.6 \%)$ & $1(1.4 \%)$ & $1(1.4 \%)$ \\
Refrigerator & 0 & 0 & $1(1.4 \%)$ & $1(1.4 \%)$ \\
Artificial Intelligence & 0 & 0 & $1(1.4 \%)$ & 0 \\
Internet & 0 & 0 & $1(1.4 \%)$ & 0 \\
Special Glasses & 0 & 0 & $1(1.4 \%)$ & $1(1.4 \%)$ \\
Flying shoe & 0 & 0 & $2(2.7 \%)$ & $1(1.4 \%)$ \\
Magic carpet & 0 & 0 & $1(1.4 \%)$ & 0 \\
Flying car & 0 & $4(11.1 \%)$ & $2(2.7 \%)$ & $2(2.7 \%)$ \\
Flying house & 0 & $1(2.8 \%)$ & 0 & $1(1.4 \%)$ \\
Fast police car & 0 & $1(2.8 \%)$ & 0 & 0 \\
Automatic piano & $1(2.8 \%)$ & 0 & 0 & 0 \\
\hline
\end{tabular}

When the images reflected by students with regards to technology used by scientist in their drawings are examined in general; it is seen that Syrian students drew "time machine", "telephone", "automatic piano", "washing machine", "tablet", "robot", "spaceship", "flying car", "flying house", "fast police car" in a limited number. There are differences in the answers of Turkish students both in quantity and variety. Turkish students drew "time machine","computer", "robot", "telephone", "spaceship", "internet", "artificial intelligence", "refrigerator", "special glasses", "flying shoe", "flying car", "flying house", "magic carpet". It is seen that common images of Syrian and Turkish children related to technology are "time machine", "spaceship", "flying car" and "flying house". The answer of "fast police car" belonging to a Syrian student confronts us again as an attention-grabbing answer. Syrian children use the concepts of "police", "police car" frequently in their pictures. 


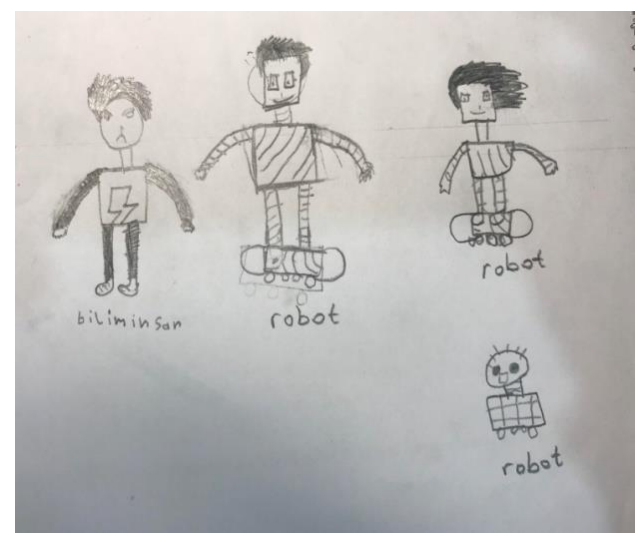

Figure 12: Scientist producing robot (Syrian Student, Male, 3. grade)

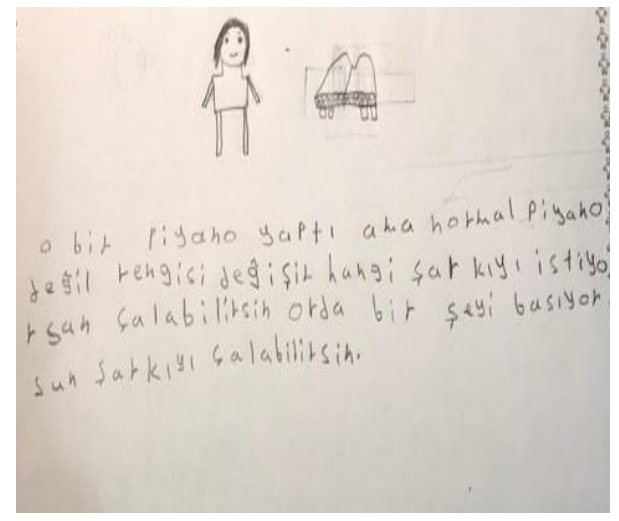

Figure 14: Scientist producing automatic piano (Syrian Student, Male, 4. grade)

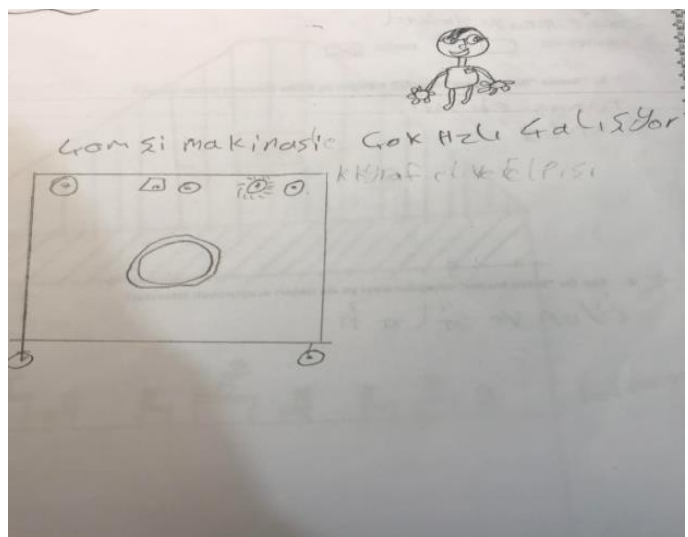

Figure 13: Scientist producing a fast washing machine (Syrian Student, Male, 4. grade)

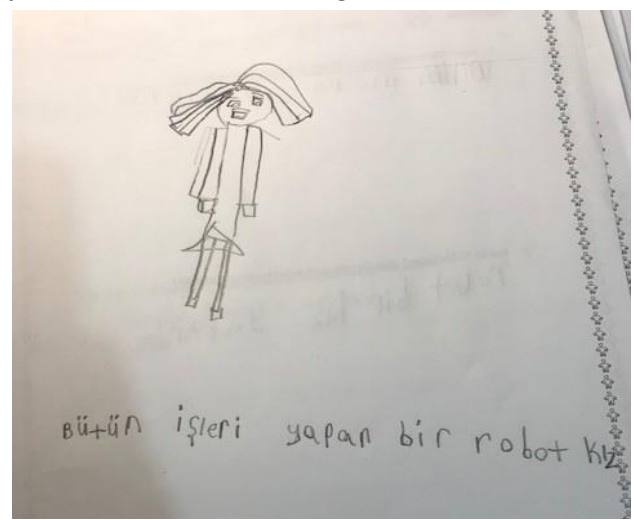

Figure 15: Scientist making a robot (Turkish, Female, 4. grade)

The images of students related to working area of scientist are given as gender and as Syrian-Turkish students seperately in Table 7.

Table 7. Frequency and percentage distribution of images related to working area of scientist whom students reflected in their drawings

\begin{tabular}{lcccc}
\hline & \multicolumn{2}{c}{ Syrian } & \multicolumn{2}{c}{ Turkish } \\
\hline Working area & Female & Male & Female & Male \\
$\mathrm{f}(\%)$ & $\mathrm{f}(\%)$ & $14(19.2 \%)$ & $6(8.2 \%)$ \\
\hline Laboratory & $1(2.8 \%)$ & 0 & $2(2.7 \%)$ & 0 \\
Sea & 0 & $2(5.6 \%)$ & $1(1.4 \%)$ & $2(2.7 \%)$ \\
Nature & $1(2.8 \%)$ & $3(8.3 \%)$ & $1(1.4 \%)$ & $2(2.7 \%)$ \\
House & $6(16.7 \%)$ & $1(2.8 \%)$ & $25(34.2 \%)$ & $14(19.2 \%)$ \\
Unidentified place & $7(19.4 \%)$ & $12(33.3 \%)$ & $2(2.7 \%)$ & $2(2.7 \%)$ \\
Space & 0 & $1(2.8 \%)$ & $1(1.4 \%)$ & 0 \\
Classroom & $1(2.8 \%)$ & $1(2.8 \%)$ & & 0 \\
\hline
\end{tabular}

When the images reflected by students with regards to working area of scientist in their drawings are examined in general; Syrian students drew places of "laboratory $(n=2)$ ", "sea $(n=2) "$, "nature $(n=4)$ ", "house $(n=7)$ ", "classroom $(n=2) "$, and "space $(n=2) "$; Turkish students drew places of "laboratory $(n=20)$ ", "sea $(n=2)$ ", "nature $(n=3)$ ", "house $(n=3)$ " and "space $(\mathrm{n}=4)$ ". 


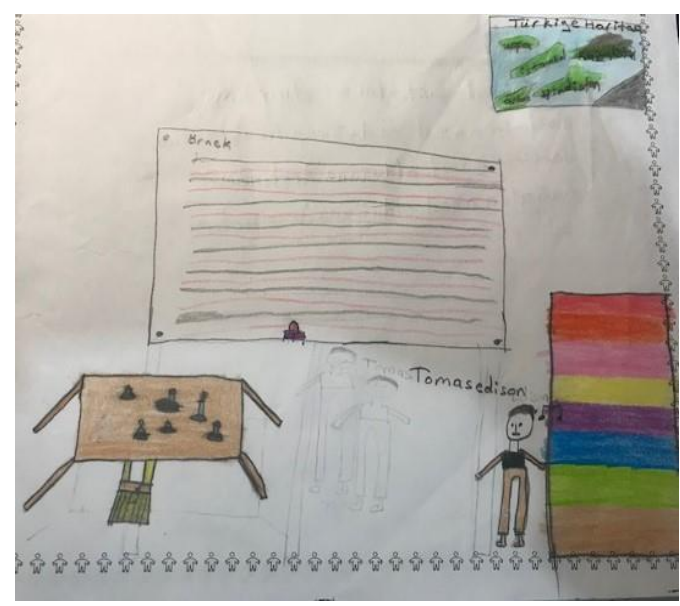

Figure 15: Scientist making experiment in the environment of a class (Turkish student, Female, 3. grade)

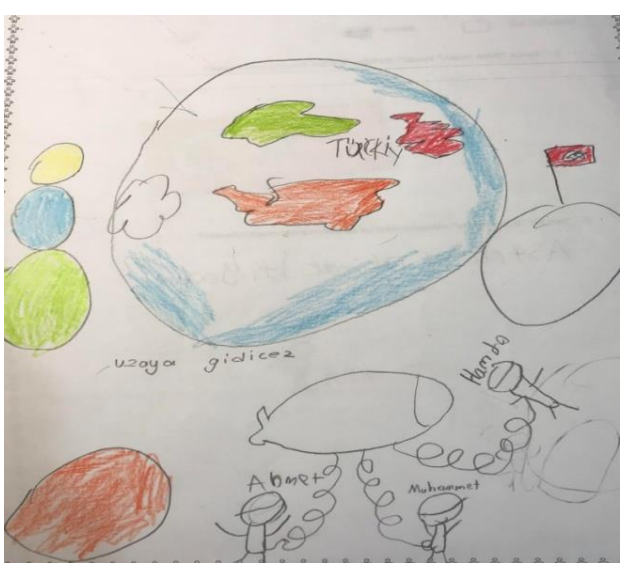

Figure 16: Scientists making research in space (Syrian student, Male, 3. grade)

The images of students related to their favourite scientists are given as gender and as Syrian-Turkish students seperately in Table 8 .

Table 8. Frequency and percentage distribution of images related to favourite scientists of students

\begin{tabular}{lcccc}
\hline \multicolumn{3}{c}{ Syrian } & Turkish & \\
\hline Scientists & $\begin{array}{c}\text { Female } \\
\mathrm{f}(\%)\end{array}$ & $\begin{array}{c}\text { Male } \\
\mathrm{f}(\%)\end{array}$ & $\begin{array}{c}\text { Female } \\
\mathrm{f}(\%)\end{array}$ & $\begin{array}{c}\text { Male } \\
\mathrm{f}(\%)\end{array}$ \\
\hline Thomas Edison & $5(13.9 \%)$ & $4(11.1 \%)$ & $22(30.1 \%)$ & $16(21.9 \%)$ \\
Albert Einstein & 0 & $1(2.8 \%)$ & $16(21.9 \%)$ & $9(12.3 \%)$ \\
Graham Bell & 0 & $2(5.6 \%)$ & $13(17.8 \%)$ & $8(11 \%)$ \\
Leonardo Da Vinci & 0 & 0 & $1(1.4 \%)$ & $2(2.7 \%)$ \\
Isaac Newton & 0 & 0 & $1(1.4 \%)$ & 0 \\
Nicola Tesla & $1(2.8 \%)$ & 0 & $4(5.5 \%)$ & $5(6.8 \%)$ \\
Marie Curie & 0 & 0 & $2(2.7 \%)$ & $2(2.7 \%)$ \\
Louis Pasteur & 0 & 0 & $4(5.5 \%)$ & $3(4.1 \%)$ \\
Pythagoras & 0 & 0 & $6(8.2 \%)$ & $4(5.5 \%)$ \\
Magellan & 0 & 0 & $5(6.8 \%)$ & $2(2.7 \%)$ \\
Avicenna & 0 & 0 & $6(8.2 \%)$ & 0 \\
Al-Jazari & $25.6 \%)$ & 0 & $1(1.4 \%)$ & $2(2.7 \%)$ \\
Al-Biruni & 0 & 0 & $6(8.2 \%)$ & 0 \\
Cahit Arf & 0 & 0 & $5(6.8 \%)$ & 0 \\
Mimar Sinan & $12.8 \%)$ & 0 & $3(4.1 \%)$ & 0 \\
Aziz Sancar & 0 & 0 & $3(4.1 \%)$ & 0 \\
Piri Reis & $2(5.6 \%)$ & 0 & $1(1.4 \%)$ & 0 \\
Niccolo Conti & 0 & 0 & $2(2.7 \%)$ & $1(1.4 \%)$ \\
Hezarfen Ahmed Çelebi & $1(2.8 \%)$ & 0 & 0 & $1(1.4 \%)$ \\
Yuri Gagarin & 0 & 0 & 0 & $1(1.4 \%)$ \\
Nikolaus Otto & 0 & 0 & $1(1.4 \%)$ & 0 \\
Willis Carrier & 0 & 0 & $1(1.4 \%)$ & 0 \\
Al Kindi & 0 & 0 & $1(1.4 \%)$ & 0 \\
James Watt & 0 & 0 & $1(1.4 \%)$ & 0 \\
Galileo Galilei & 0 & 0 & 0 & $1(1.4 \%)$ \\
Archimedes & 0 & 0 & 0 & $1(1.4 \%)$ \\
Ali Kuşcu & 0 & 0 & $1(1.4 \%)$ & 0 \\
Charles Bob & 0 & 0 & $1(1.4 \%)$ & 0 \\
Elisha Olis & 0 & 0 & $1(1.4 \%)$ & 0
\end{tabular}




\begin{tabular}{lcccc} 
Karl Friedrich Benz & 0 & 0 & $1(1.4 \%)$ & $1(1.4 \%)$ \\
Igor Skorsky & 0 & 0 & 0 & $1(1.4 \%)$ \\
Bobbit & 0 & 0 & $1(1.4 \%)$ & 0 \\
Jacob Perkins & 0 & 0 & 0 & $1(1.4 \%)$ \\
Fuat Sezgin & 0 & 0 & $1(14 \%)$ & 0 \\
Gazi Yaşargil & 0 & 0 & $1(1.4 \%)$ & 0 \\
George De Mestral & 0 & 0 & $1(1.4 \%)$ & 0 \\
Robert Hooke & 0 & 0 & $1(1.4 \%)$ & 0 \\
Other & $1(5.6 \%)$ & 0 & 0 & 0 \\
\hline
\end{tabular}

When the images reflected by students with regards to their favourite scientists are examined in general; Syrian students specified the names of "Thomas Edison" (n=9), "AlJazari" ( $n=2)$, "Piri Reis" ( $n=2)$, " Nicola Tesla" ( $n=1)$, " Hezarfen Ahmed Çelebi" ( $n=1)$. But, in the table under the title of "other" two students answered as "Elvis Presley and Agatha Christie" when called scientist. It is seen that they mixed the concepts of scientist and artist. It is seen that Turkish students mentioned so many scientists from different study areas in their drawings. Turkish students like Syrian students sorted as "Thomas Edison" $(n=38)$ at the first place, "Albert Einstein" ( $=25)$ as second and "Graham Bell" $(n=21)$ as the third. When the scientists shared by Turkish students are examined, it is seen that they mentioned Turkish scientists as well as foreign scientists. Scientist such as "Cahit Arf", "Aziz Sancar", "Gazi Yaşargil", "Ali Kuşçu" draw attention. But the percentage of the answers given is not as higher as the answers given as foreign scientists. Students predominantly share foreign scientists as answer.

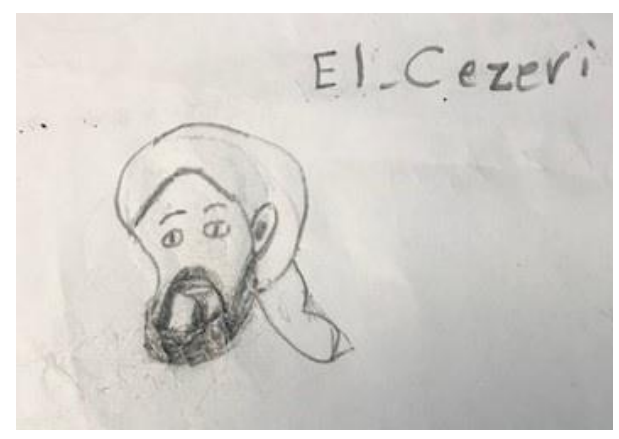

Figure 17: A drawing representing Al-Jazari (Syrian, Female, 4. Grade)

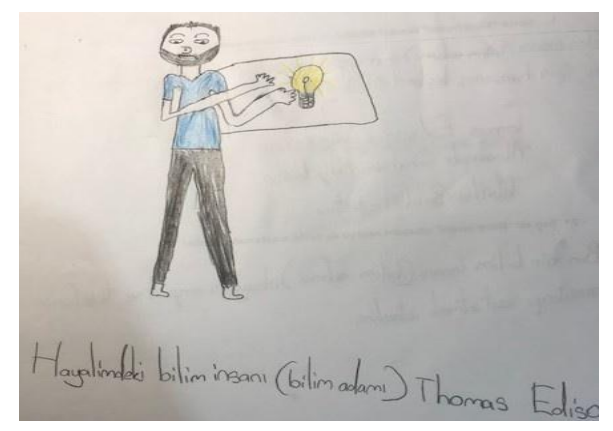

Figure 18: A drawing representing Thomas Edison (Turkish, Female, 4. Grade)

\section{Discussion, Result and Suggestions}

In general, within the scope of this research, the scientist perceptions of the Syrian students who immigrate from their country because of war and Turkish students attending to same classroom researched deeply. In this context, the drawings of Syrian and Turkish students are analysed in detail. Codings were performed under 7 different themes in total. It was seen that in general, the drawings of Syrian children are quite limited compared to Turkish children. Especially, three of Syrian children drawing "policeman" picture when called scientist shows how much the children were affected from the events they had experienced. Turkish flag and Turkey love draw attention in the drawings of Syrian children. Another attention-grabbing point while the drawings are examined is that both all Turkish and Syrian male children drew "male" figure when called scientist. There was no male student drawing "female" scientist. Approxiametely $30 \%$ of both Syrian and Turkish students among female students drew female scientist. In consequence of the acquired findings, similarities are seen when the other studies conducted about scientist perception in the literature (Chambers, 1983; Mead and Metraux, 1957; Barman, 1997) are examined. Unfortunately; today "male" figure domination still continues when it is called scientist. Even bigger part of the female students drew "male" as scientist. In this scope, for the consideration of scientist concept indepently from gender, 
our teachers should refer to successful scientists raised in our country. In particular, various awareness studies can be conducted about female scientists. School-wide activities can be carried out related to scientists.

As for physical characteristics of scientist both student group described scientist as someone "who has firmly combed hair, wears firm clothes". Drawings including woman dress and suit are more than the ones including scientists wearing laboratory coats. This finding differs from the other studies in the literature. While in the most of previous studies (Mead and Metraux, 1957; Korkmaz and Kavak, 2010) children characterized scientist as having straggly hair and bedraggled, the scientist perception of today transformed into a straighter and firm person.

As for research symbols used by scientist, while Syrian students gave place to the symbols of microscope, clock, pallet, bulb and ship, Turkish students gave place to much more various symbols (vaccine, stethoscope, organs, scales, medicine, fossile, telescope, atom, dinosaur, planet). Also, the images which students reflected with regards to knowledge symbols used by scientist in their drawings differs. While Syrian students drew only pen and board, Turkish students drew the symbols of book, pen, formulas, coordinates, dry ice, gravity, virus and micrope. Also, in this category, it is seen that knowledge symbols images of Syrian students is quite limited. Especially, in science classes the lives of scientists can be told through stories their story can be read. Animation activities can be carried out with drama method. Activities improving the showing emphaty skills of children towards scientist should be given place.

When the images reflected by students with regards to technology used by scientist in their drawings are examined in general; it is seen that the common images of Syrian and Turkish children related to technology are time machine, spaceship, flying car and flying house. Again it drew attention that image variety in Turkish students are much more. For example; the concept of artificial intelligence is just encountered in the drawings of Turkish children. It could be ensured that children keep up with the latest developments throught the world by enabling them to follow up Tübitak popular science books and publishings like "Bilim Çocuk" (Science Kid) magazine starting from the primary school and also by making them watch videos, animations from scientific resources in the related subjects. Teachers should be instructive in the subjects which are on the agenda in recent years such as robotics, coding, space researches, artificial intelligence.

As for working area of scientist, in general most students abstained from specifying a place in both student groups. While a clear majority of Turkish students drew scientist while making experiments in the laboratory, Syrian students mostly drew them while studying in the nature or at home. These findings show similarity with the study of Song and Kim (1999). In this scope, some out-of-class activities, excursions can be organized in order to emphasize that scientists are not able to make studies only in the laboratory environment but also in different environments. The working area of scientists who work in different branches can be given as an example in the lessons.

When the drawings under the category of favourite scientist are examined, Thomas Edison took the first place in the favourite scientist rankings of both Syrian and Turkish students. Syrian students specified "Al-Jazari", "Piri Reis", " Nicola Tesla" and "Hezarfen Ahmed Çelebi" respectively following Thomas Edison. Turkish students told "Albert Einstein" and "Graham Bell" in the third place. Similarly, in the study of Korkmaz and Kavak (2010) students ranked "Einstein" in the first place as favourite scientist and then "Edison", "Marie Curie", Graham Bell, Newton, Robert Boyle, Archimedes, Pasteur, Leonardo Da Vinci, Avicenna et. al respectively. All students shared foreign scientists as answer more than Turkish scientists. This finding is quite attention-grabbing. Unfortunately, although there are quite successful scientists raised in our country, only few children shared these names. In this context, Turkish scientists who have studies in the related area should be especially mentioned while the curriculum is implemented in all lessons, science lessons being in the first place and in club studies like science club in primary school. Events (conferences, interviews, etc.) can be arranged to meet with students and scientists who are alive and have innumerable contributions to science. A large number of valuable scientists trained in our country still work in many of the world's number of institutions and universities. The messages that these 
valuable scientists, who can be reached very easily even through social media, will give children early on is also very important. Appropriate books to the level of children telling about the lives of scientists can also be recommended for reading in their spare time.

One of the most important aspects of the research was the comparison of scientists' perceptions of Syrian and Turkish students. In the consequence of this study, it is seen that in general Syrian students gave limited answers compared to Turkish students with regards to scientist perception. It was seen that problems were experienced with Syrian students about language in the school which was visited for implementation. Since the children were not able to express themselves in a language different from their mother language comfortably, they experienced difficulties in drawing compared to Turkish students. The need of Syrian students gaining Turkish language skills which they can communicate with their teachers and each other obviously confronts us. When the other studies conducted with Syrian children are examined, it is specified that they find it difficult to get on with their compeers and so they mostly become lonely due to not socializing, and teachers feel themselves insufficient about solving the problem because of not confronting such a situation before and they are torn between the families of the other children in their classroom and refugee children (Uzun ve Bütün, 2016, p.79). In this context, plannings should be performed with regards to integration of also Syrian students to education process. Precautions must be taken in order to eliminate these differences in science and scientist perceptions of children who are in the same age group who study at the same grade, and same school. School administration and teachers may organize activities with the parents of Syrian students during out-of-class period. Form teachers should plan the education process by considering the differences between the children while implementing the curriculum. All educators, academicians should display the required sensitivity for all children living in the same society benefiting from similar conditions.

\section{References}

Balkı, N., Çoban, A. K., \& Aktaş, M. (2003). Ilköğretim öğrencilerinin bilim ve bilim insanına yönelik düşünceleri. Uludağ Üniversitesi Eğitim Fakültesi Dergisi, 17(1), 11-17.

Barman, C. (1997). Students' views of scientist and science: results from a national study. Science and Children, 35, 18-23.

Büyükikiz, K. K., \& Çangal, Ö. (2016). Suriyeli misafir öğrencilere Türkçe öğretimi projesi üzerine bir değerlendirme. Uluslararası Türkçe Edebiyat Kültür Eğitim (TEKE) Dergisi, 5(3), 1414-1430.

Chambers, D.W. (1983). Stereotypic images of the scientist: the draw a scientist test. Science Education, $67(2), 255-265$.

İdin, Ş. (2018). The challenges of refugee students encountered in science courses: A phenomenological study. Journal of Education and Future, (13), 79-94.

Karasar, N. (1999). Bilimsel araştırma yöntemi, Ankara: Nobel.

Korkmaz, H., \& Kavak, G. (2010). İlköğretim öğrencilerinin bilime ve bilim insanına yönelik imajları. Illkögretim Online, 9(3), 1055-1079.

Mead, M., \& Metreaux, R. (1957). The image of science among high school students. Science, 126, 384-390.

Miles, M. B., \& Huberman, A. M. (1994). Qualitative data analysis: An expanded sourcebook. Sage.

Sakız, H. (2016). Göçmen çocuklar ve okul kültürleri: Bir bütünleştirme önerisi. Göç Dergisi, 3(1), 6581.

Seydi, A. R. (2014). Türkiye'nin Suriyeli sığınmacıların eğitim sorununun çözümüne yönelik izlediği politikalar. Süleyman Demirel Üniversitesi Fen-Edebiyat Fakültesi Sosyal Bilimler Dergisi, 2014 (31), 267-305.

Song, J., \& Kim, K. S. (1999). How Korean students see scientists: the image of the scientist. International Journal of Science Education, 21(9), 957-977.

Toğrol, A. Y. (2000). Öğrencilerin bilim insanı ile ilgili imgeleri. Eğitim ve Bilim, 25(118), 49-56.

Türkmen, H. (2008). Turkish primary students' perceptions about scientist and what factors affecting the 1mage of the scientists. Eurasia Journal of Mathematics, Science And Technology Education, $4(1), 55-61$. 


\section{THE COMPARISON OF SCIENTIST PERCEPTIONS OF SYRIAN REFUGEE STUDENTS AND TURKISH STUDENTS: SAMPLE OF MERSIN PROVINCE}

Uzun, E. M., \& Bütün, E. (2016). Okul öncesi eğitim kurumlarındaki Suriyeli sığınmacı çocukların karşılaştıkları sorunlar hakkında öğretmen görüşleri. Uluslararası Erken Çocukluk Eğitimi Çalı̧̧maları Dergisi, 1(1), 72-83.

Yavuz, Ö., \& Mızrak, S. (2016). Acil durumlarda okul çağındaki çocukların eğitimi: Türkiye'deki suriyeli mülteciler örneği. Göç Dergisi, 3(2), 175-199.

Yıldırım, A., \& Şimşek, H. (2006). Sosyal bilimlerde nitel araştırma yöntemleri. Ankara: Seçkin. 